4-23-2005

\title{
Snowpack control over the thermal offset of air and soil temperatures in eastern North Dakota
}

Andrew Grundstein

Paul E. Todhunter

University of North Dakota, paul.todhunter@und.edu

Thomas Mote

How does access to this work benefit you? Let us know!

Follow this and additional works at: https://commons.und.edu/geo-fac

Part of the Geography Commons

\section{Recommended Citation}

Andrew Grundstein, Paul E. Todhunter, and Thomas Mote. "Snowpack control over the thermal offset of air and soil temperatures in eastern North Dakota" (2005). Geography \& Geographic Information Science Faculty Publications. 3.

https://commons.und.edu/geo-fac/3

This Article is brought to you for free and open access by the Department of Geography \& Geographic Information Science at UND Scholarly Commons. It has been accepted for inclusion in Geography \& Geographic Information Science Faculty Publications by an authorized administrator of UND Scholarly Commons. For more information, please contact und.commons@library.und.edu. 


\title{
Snowpack control over the thermal offset of air and soil temperatures in eastern North Dakota
}

\author{
Andrew Grundstein, ${ }^{1}$ Paul Todhunter, ${ }^{2}$ and Thomas Mote ${ }^{1}$ \\ Received 24 January 2005; revised 16 March 2005; accepted 25 March 2005; published 23 April 2005.
}

[1] The close relationship between air and ground temperatures has been used to reconstruct paleoclimate conditions from ground temperatures. Unfortunately, the presence of snow decouples air and ground temperatures and obscures their relationship. The objective of this paper is to investigate the role that snowpack conditions play in affecting the relationship between air and soil temperatures. The annual thermal offset between mean annual soil and air temperatures is examined over a 12 year period (1990-2002) at Fargo, ND, using observed soil temperatures along with simulations from a physically based snowpack model. Early season snow cover does not necessarily lead to large thermal offsets. These snowpacks, while low in density, also tended to be shallow and therefore do not provide much thermal insulation. Winter snowpacks explain a greater portion of the annual thermal offset. While denser than fall snowpacks, the extra depth and longer persistence leads to superior insulation of the ground. Citation: Grundstein, A., P. Todhunter, and T. Mote (2005), Snowpack control over the thermal offset of air and soil temperatures in eastern North Dakota, Geophys. Res. Lett., 32, L08503, doi:10.1029/2005GL022532.

\section{Introduction}

[2] Variations in soil temperature have important biological, agricultural, and climatic consequences. As such, there has been a considerable body of research that explores the links between air and soil temperatures and the factors that govern air-soil energy exchanges. The relationship between atmospheric and ground temperatures has been used to reconstruct past climate conditions (air temperature) from borehole temperatures [Lachenbruch and Marshall, 1986; Beltrami and Mareschal, 1992; Shen and Beck, 1992; Wang et al., 1992; Smerdon et al., 2003; Pollack and Smerdon, 2004]. These reconstructions assume that conduction is the dominant means of heat transfer in the soil [Smerdon et al., 2003] and that soil temperatures track air temperatures in a consistent and regular manner over long periods of time [González-Ruoco et al., 2003]. Gosnold et al. [1997] and Majorowicz and Skinner [1997], however, have questioned this premise in certain locations by noting that snow cover duration and depth, as well as the release of latent heat of fusion can influence how air and soil temperatures track one another during the winter. USA.

${ }^{1}$ Department of Geography, University of Georgia, Athens, Georgia,

${ }^{2}$ Department of Geography, University of North Dakota, Grand Forks, North Dakota, USA.

Copyright 2005 by the American Geophysical Union. 0094-8276/05/2005GL022532\$05.00
[3] The role of snow cover and its timing, duration, and physical characteristics on the ground thermal regime has been explored principally through model simulations and sensitivity tests [Goodrich, 1982; Zhang et al., 1996, 1997; Ling and Zhang, 2003]. There has been little long-term empirical research on the relationship between soil temperatures, and the presence and condition of the snow cover [Schmidt et al., 2001]. Of the studies done, most rely on snow cover duration or average snow depth, omitting important information on the quality of the snowpack.

[4] This project builds upon the empirical work of Schmidt et al. [2001] by incorporating modeled snowpack output with observed soil and air temperature data over a 12-year period (1990-2002) at Fargo, ND. The annual thermal offset is investigated in conjunction with snow cover and snowpack characteristics. A physically based snowpack model (SNTHERM) provides details of the snowpack structure such as density and thermal conductivity that are typically not measured, allowing for a more complete analysis of the role of different snowpack conditions on soil/air temperature relationships.

\section{Snow and Soil Data and Model Evaluation}

[5] Fargo, ND is used as a study site for this project. This is an ideal location for such a study because of the reliable seasonal snow cover and the presence of both a National Weather Service (NWS) station $\left(46.93^{\circ} \mathrm{N}, 96.81^{\circ} \mathrm{W}\right)$ and a North Dakota Agricultural Weather Network (NDAWN) station $\left(46.89^{\circ} \mathrm{N}, 96.79^{\circ} \mathrm{W}\right)$. Daily average soil temperature data at a depth of $10.5 \mathrm{~cm}$ were obtained from the NDAWN station. This dataset extends from 1990 through to the present. Snowpack parameters such as depth and density as well as thermal conductivity were obtained as output from a physically based snowpack model (SNTHERM version 4) [Jordan, 1991]. The model was run for the period from 1990 through 2002 and requires meteorological input data that includes hourly precipitation, temperature, relative humidity, as well as wind speed. These data were obtained from observations at the Fargo National Weather Service (NWS) station which is located $4.7 \mathrm{~km}$ from the NDAWN station.

[6] Daily snow depth and snow density output from SNTHERM (taken at 7 a.m. LST) were compared against daily data collected at nearby observing stations. Snow depth data are from the NWS station until 1998/99 when the Automatic Service Observing Station (ASOS) was commissioned and thereafter from a cooperative observing station in Moorhead Minnesota $\left(46.88^{\circ} \mathrm{N}, 96.75^{\circ} \mathrm{W}\right)$ which is located approximately $7 \mathrm{~km}$ from the Fargo NWS station. The Moorhead data are accepted by the NWS as the official snow depth data for Fargo. Snow water equivalent (SWE) observations from the Fargo NWS station were available 


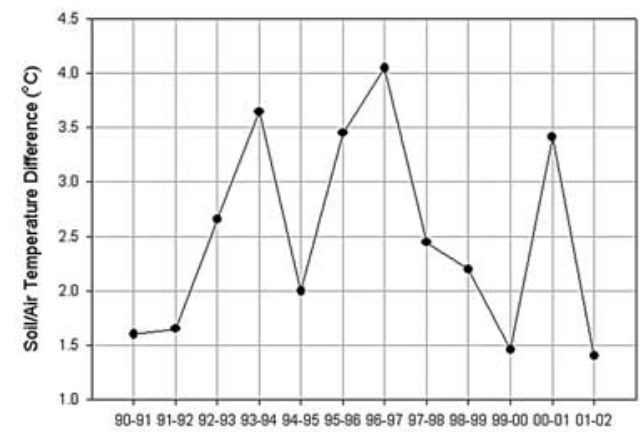

Figure 1. Annual thermal offset between mean annual air temperature and mean annual soil temperature at $10.5 \mathrm{~cm}$ for the 1990/91 through 2001/02 seasons at Fargo.

through the $1995 / 96$ season. Snow densities at the NWS station were estimated from the snow depth and SWE data. Since the SWE measurements are officially taken at 1800 UTC (12 p.m. LST) and snow depth measurements are collected at 1200 UTC (6 a.m. LST), inaccurate estimates in snow density may occur on days where snow accumulates, settles, or ablates between observing times [Schmidlin, 1990].

[7] The SNTHERM snow output does a good job of modeling snowpack conditions. The average modeled snow depth $(0.24 \mathrm{~m})$ is greater than the observed value $(0.21 \mathrm{~m})$. However, they vary in a similar manner $(r=0.81)$. To assess the "agreement" between the observed and predicted snow depths, the index of agreement (d) [Gaile and Willmott, 1984] is used. This is a bounded model evaluation statistic that incorporates the root mean square error (RMSE) and falls between zero (no relationship) and 1.0 (perfect relationship). Here, $d=0.89$ indicating that SNTHERM output accurately simulates the snow depth conditions. A comparison of snow densities between the observed and modeled was only possible from 1990/91 through 1995/96. Average snowpack densities were compared for days with observed snow depths greater than $5 \mathrm{~cm}$ to emphasize those days with deeper snowpacks and superior insulation. On average, modeled snowpack densities $\left(202 \mathrm{~kg} \mathrm{~m}^{-3}\right)$ are greater than those computed from NWS observations $\left(165 \mathrm{~kg} \mathrm{~m}^{-3}\right)$. As with snow depth, the "observed" and modeled densities vary in a similar manner as indicated by $\mathrm{r}=0.61$ and $\mathrm{d}=$ 0.60 . The relationships are not as strong as with snow depth. In part, this may be due to the fact that "observed" densities were computed from measured snow depths and SWE which were sampled in different locations and at different times.

\section{Methodology}

[8] The influence of snowpack insulation on the soil/air separation is investigated by using the annual thermal offset. The annual thermal offset is calculated as the difference between the mean annual soil temperature at $10.5 \mathrm{~cm}$ and the mean annual air temperature at shelter height. The annual values for soil and air temperatures were computed from 1 July to 30 June of the following year to capture a complete snow year. Within this snow year, fall is defined as the months of September, October, and November; winter as December, January, and February; and spring as March, April, and May.

[9] Snow cover days and snowpack thermal resistance are determined from model output and calculated for the snow year as well as for fall, winter, and spring. The insulating capacity of the snowpack or thermal resistance (TR; $\mathrm{K} \mathrm{m}^{2} \mathrm{~W}^{-1}$ ) is defined as $\mathrm{TR}=\mathrm{H} / \mathrm{K}$ where $\mathrm{H}$ is the snow depth $(\mathrm{m})$ and $\mathrm{K}$ is the thermal conductivity of the snowpack ( $\mathrm{W} \mathrm{m}^{-1} \mathrm{~K}^{-1}$ ) [Zhang et al., 1996]. The thermal resistance term can be calculated by summing up the thermal resistance values of individual snowpack layers for days in the fall, winter, spring, and total snow year.

\section{Results}

\subsection{Interannual Characteristics of Thermal Offset and} Snow Characteristics

[10] The mean annual thermal offset between the soil and air temperatures is $2.5^{\circ} \mathrm{C}$. This temperature separation, however, is not constant from one year to the next (Figure 1). Rather, it ranges from slightly under $1.5^{\circ} \mathrm{C}$ in the $1999 / 00$ season to over $4.0^{\circ} \mathrm{C}$ in the $1996 / 97$ season. As has been documented by the work of Schmidt et al. [2001], the decoupling of soil and air temperatures is related to both snow cover and latent heat of fusion effects. The following sections will explore snow cover and snowpack characteristics during the study period and the role they play in influencing the magnitude of the soil/air temperature difference.

[11] The period from 1990 through 2002 contains seasons with a variety of snowpack and snow cover conditions (Table 1). Snow cover days are defined as any day with snow present on the ground and average snow depths are calculated only from days with snow. The total number of snow cover days varied from the lowest of 77 to a high of 146. By season, the fall typically had the fewest snow cover days, averaging just over 13 days, as well as the lowest average snow depths, and the lowest average snow densities. All the study years had a large number of snow days during the winter, ranging from 66 to 90 . The winter also had snow depths averaging $21 \mathrm{~cm}$ and snow densities that were in between the spring and fall values. The spring averaged 24 days but with considerable variability from one year to the next. The spring had similar average snow depths as the winter but a higher average density.

[12] The seasonal total thermal resistance values varied ranged from approximately 50 to $270 \mathrm{~K} \mathrm{~m}^{2} \mathrm{~W}^{-1}$ (Table 1). The fall snow cover provided little thermal resistance in any of the years, with an average value of just under $7 \mathrm{~K} \mathrm{~m}^{2} \mathrm{~W}^{-1}$. The greatest thermal resistance occurs during the winter with an average value of approximately $110 \mathrm{~K} \mathrm{~m}^{2} \mathrm{~W}^{-1}$; Spring has an average thermal resistance value of $19 \mathrm{~K} \mathrm{~m}^{2} \mathrm{~W}^{-1}$.

\subsection{Snow and Its Effect on Soil/Air Temperature Differences}

[13] The number of snow cover days and the thermal resistance by season and for the whole year were compared with the mean annual thermal offset between air and soil temperatures. Both the total annual number of snow cover days and thermal resistance explain a considerable amount of the variance in the thermal offset at $r^{2}=0.57$ and 0.79 respectively. There is clearly some relationship be- 
Table 1. Seasonal Snow Properties: Depth (cm), Density $\left(\mathrm{kg} \mathrm{m}^{-3}\right)$, Thermal Resistance (TR; $\mathrm{K} \mathrm{m}^{2} \mathrm{~W}^{-1}$ )

\begin{tabular}{llrrrrr}
\hline \multirow{5}{*}{ Fall } & & Mean & S.D. $^{\text {a }}$ & Max & Min & N \\
& Snow Days & 13 & 11 & 26 & 0 & 159 \\
& Depth & 9 & 9 & 48 & 1 & \\
& Density & 170 & 57 & 353 & 53 & \\
\multirow{5}{*}{ Winter } & TR & 7 & 8 & 27 & 0 & \\
& Snow Days & 84 & 9 & 90 & 66 & 1006 \\
& Depth & 21 & 15 & 78 & 1 & \\
& Density & 207 & 68 & 518 & 53 & \\
\multirow{5}{*}{ Spring } & TR & 110 & 64 & 224 & 40 & \\
& Snow Days & 24 & 11 & 45 & 11 & 287 \\
& Depth & 20 & 14 & 59 & 0 & \\
& Density & 269 & 110 & 657 & 62 & \\
& TR & 19 & 18 & 54 & 1 & \\
& Sotal & 121 & 22 & 146 & 77 & 1452 \\
& TR & 135 & 80 & 271 & 47 & \\
\hline
\end{tabular}

${ }^{\text {a }}$ S.D. is standard deviation.

tween snow cover days and thermal resistance $\left(\mathrm{r}^{2}=0.37\right)$ but the lower explained variance of snow cover presence is related to the fact that it represents only one element among many that affect the insulating quality of the snowpack. Data on thermal resistance is not commonly available and researchers must often use surrogate values. Schmidt et al. [2001] used accumulated snow depth over the season as a proxy for the thermal insulating quality of the snowpack. This term serves as an excellent substitute for thermal resistance at the Fargo study site with a near perfect explained variance of 0.96 .

[14] The effect of snow cover days and thermal resistance on the separation of soil and air temperatures is also explored by season. The fall snow cover days and thermal resistance show very little statistical relationship with the soil/air temperature separation. The lack of statistical relationship is explained by the low thermal resistance of snowpacks during the fall that do not effectively insulate the ground, primarily due to the typically low snow depths. There is a somewhat greater explained variance in the winter $\left(r^{2}=0.31\right)$ for snow cover days than found during the fall. In contrast, the winter thermal resistance explains a great deal of the variance of the soil/air temperature difference $\left(r^{2}=0.77\right)$. This can be attributed to the superior insulating properties of the winter snowpacks that are more persistent and on average deeper than in fall and less dense on average than those in the spring (Table 1). The largest $\mathrm{r}^{2}$ value of 0.74 for snow cover days is found in the spring. Since there is little variability in snow cover days during the winter, the added days in spring contribute substantially to the total snow cover days for the snow year. The $\mathrm{r}^{2}$ for thermal resistance in spring is fairly large at 0.46 . On average spring snowpacks are similar in depth to those in winter but are also denser, which leads to less effective insulation of the stored energy in the ground.

\subsection{Interannual Variation in Snow and Soil/Air Temperature Separation}

[15] The interannual and intraseasonal variations in snow cover days and thermal resistance are depicted in Figures 2a and $2 \mathrm{~b}$, respectively. There is no particular trend in snow days or thermal resistance values over the 12-year study period. Nevertheless, thermal resistance values in the late 1990's through 2002 tended to be low. Indeed, the three lowest values in the study $(1997 / 98,1999 / 00$, and 2001/02) are found during this period.

[16] The magnitude of the soil/air differences closely matches the thermal resistance but not always the number of snow cover days. The thermal offset, thermal resistance, and snow days were ranked to investigate the degree of association. Spearman's rank-order correlation coefficient $\left(r_{s}\right)$ reveals the stronger relationship of thermal offset with thermal resistance $\left(r_{\mathrm{s}}=0.81\right)$ than with snow days $\left(\mathrm{r}_{\mathrm{s}}=0.63\right)$.

[17] Stratifying the years with the largest and smallest thermal offsets reveals distinct differences in snow cover. The snow years with the largest separation between soil and air temperatures of over $3.4^{\circ} \mathrm{C}$ are $1993 / 94,1995 / 96$, 1996/97, and 2000/01 (Figure 1). For these years, both snow cover days (aside from 1995/96) and thermal resistance were among the highest values. The seasons 1993/94, $1995 / 96$, and 1996/97 had particularly large values, exceeding $240 \mathrm{~K} \mathrm{~m}^{2} \mathrm{~W}^{-1}$. It is also interesting to note that fall snow cover did not necessarily correspond with a large soil/air temperature difference. The 1993/94 and 2000/01 seasons provided the first and second greatest amounts of fall snow in the study period. However, both 1995/96 and 1996/97 have few snow cover days during the fall and little insulation of the ground. Also, a large number of snow cover days, as occurred in 1992/93, does not always correspond to a large seasonal thermal resistance value and a large soil/air temperature difference.

[18] The years with the smallest annual average soil/air temperature differences, less than $1.7^{\circ} \mathrm{C},(1990 / 91,1991 / 92$, 1999/00, and 2001/02) had on average 36 fewer snow days and less than one-third of the thermal resistance of the four years with the largest soil/air temperature differences. These
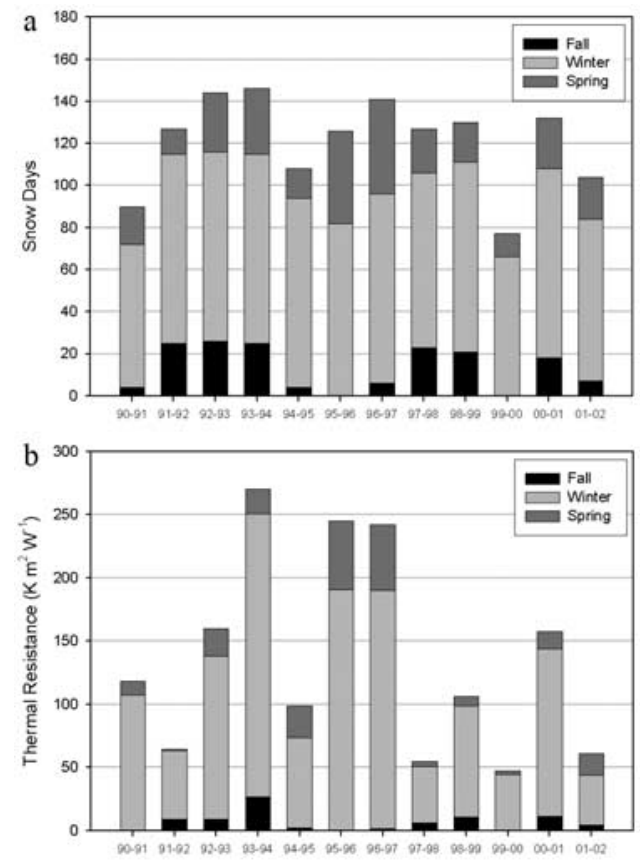

Figure 2. (a) Seasonal and annual snow cover days for the 1990/91 through 2001/02 seasons at Fargo. (b) Seasonal and summed thermal resistance for the 1990/91 through 2001/02 seasons at Fargo. 
years tended to have the fewest snow cover days and the lowest thermal resistance values. There are discrepancies such as $1997 / 98$ with the second lowest thermal resistance value but a soil/air separation that is near the average at $2.45^{\circ} \mathrm{C}$. In part, this may be due to the microclimatic and surface type variations between the NDAWN site and the NWS site where data to drive the snowpack model were obtained. First, the modeled snow depths are shallower than observed NWS values, with peak observed snow depths in January and February approximately $6 \mathrm{~cm}$ less. Also, the NDAWN soil temperatures (not shown) are higher than the modeled ones and are relatively constant from November through March, suggesting that the snowpack at the NDAWN site may have been deeper and provided better insulation.

\section{Summary and Conclusions}

[19] This study used modeled snowpack output in conjunction with measured soil temperature data to investigate how snowpack qualities like density and thermal conductivity influence snowpack thermal insulation and the decoupling of soil and air temperatures.

[20] Over the study period, the annual average soil/air temperature difference varied from $1.5^{\circ} \mathrm{C}$ to over $4.0^{\circ} \mathrm{C}$. The number of snow cover days is related to the soil/air temperature separation but the influence is not uniform. For instance, the 1992/93 and 1993/94 seasons have a similar number of snow cover days but a very different thermal offset. The important distinction is that in 1993/94, the snowpack had a considerably greater thermal resistance due mainly to greater snow depths which averaged $37 \mathrm{~cm}$ versus $19 \mathrm{~cm}$ for 1992/93.

[21] The thermal resistance explains a greater portion of the variation in soil/air temperature separations than snow cover duration over the snow year. Seasonally, the fall snowpacks, while low in density on average, also tended to be shallow. Thus, they provided little thermal insulation and do not explain a large portion of the variance in soil/air temperature departures. Winter and spring snowpacks on average are deeper but also denser than fall snowpacks. The extra depth and longer persistence, however, leads to superior insulation. Snow cover is not the only variable that has been shown to be related to the decoupling of the air and soil temperatures. The latent heat released as soil freezes can also be important [Schmidt et al., 2001]. Soil moisture data were not available for this study but Schmidt et al. [2001] noted that latent heat released from freezing soil correlates highly with fall precipitation prior to ground freezing. Rainfall data from the Fargo ASOS station were totaled for September, October, and November. It shows a statistically significant (at the $95 \%$ level) positive trend towards an increase in fall precipitation. This corresponds with observed increases in soil temperatures despite no similar increase in air temperatures. Future work may explore the role of soil moisture in greater detail.

[22] In cold climate regions experiencing a seasonal snow cover, the thermal offset between mean annual air and soil temperatures is not constant but varies with snow cover duration, snowpack conditions, and soil moisture content at the time of winter soil freezing. If the interannual variations in these factors are randomly distributed over long periods of time, then their effects would be smoothed as heat diffuses into the ground, and the borehole temperature record would continue to maintain a consistent tracking of the air temperature. Systematic long-term positive or negative trends in any of these variables, however, could introduce non-atmospheric temperature trends into the borehole temperature record. This finding has implications for borehole paleoclimate work in cold regions.

[23] Acknowledgment. This material is based upon work supported by the National Science Foundation under grant number 0318384.

\section{References}

Beltrami, H., and J.-C. Mareschal (1992), Ground temperature changes in eastern Canada: Borehole temperature evidence compared with proxy data, Terra Nova, 5, 21-28.

Gaile, G. L., and C. J. Willmott (1984), On the evaluation of model performance in physical geography, in Spatial Statistics and Models, Theor. Decis. Libr., vol. 40, edited by G. L. Gaile and C. J. Willmott, pp. 443-460, Springer, New York.

Goodrich, L. E. (1982), The influence of snow cover on the ground thermal regime, Can. Geotech. J., 19, 421-432.

González-Ruoco, F., H. von Storch, and E. Zorita (2003), Deep soil temperature as proxy for surface air-temperature in a coupled model simulation of the last thousand years, Geophys. Res. Lett., 30(21), 2116, doi:10.1029/2003GL018264.

Gosnold, W. D., P. E. Todhunter, and W. Schmidt (1997), The borehole temperature record of climate warming in the mid-continent of North America, Global Planet. Change, 15, 33-45.

Jordan, R. (1991), A one dimensional temperature model for a snow cover: Technical documentation for SNTHERM.89, Spec. Rep. 91-16, U.S. Army Corps of Eng., Cold Reg. Res. and Eng. Lab., Hanover, N. H.

Lachenbruch, A., and B. V. Marshall (1986), Changing climate: Geothermal evidence from permafrost in the Alaskan Arctic, Science, 234, 689-696.

Ling, F., and T. Zhang (2003), Impact of the timing and duration of seasonal snow cover on the active layer and permafrost in the Alaskan Arctic, Permafrost Periglacial Processes, 14, 141-150.

Majorowicz, J. A., and W. R. Skinner (1997), Anomalous ground warming versus surface air warming in the Canadian prairie provinces, Clim. Change, 35, 485-500.

Pollack, H. N., and J. E. Smerdon (2004), Borehole climate reconstructions: Spatial structure and hemispheric averages, J. Geophys. Res., 109, D11106, doi:10.1029/2003JD004163.

Schmidlin, T. W. (1990), A critique of the climatic record of "water equivalent of snow on the ground" in the United States, J. Appl. Meteorol., 29, $1136-1141$.

Schmidt, W. L., W. D. Gosnold, and J. W. Enz (2001), A decade of air-ground temperature exchange from Fargo, ND, Global Planet. Change, 29, 311-325.

Shen, P. Y., and A. E. Beck (1992), Paleoclimate change and heat flow density inferred from temperature data in the superior province of the Canadian shield, Paleaeogeogr. Palaeoclimatol. Palaeoecol., 98, $113-127$.

Smerdon, J. E., H. N. Pollack, J. W. Enz, and M. J. Lewis (2003), Conduction-dominated heat transport of the annual temperature signal in soil, J. Geophys. Res., 108(B9), 2431, doi:10.1029/2002JB002351.

Wang, K., T. J. Lewis, and A. M. Jessop (1992), Climatic changes in central and eastern Canada inferred from deep borehole temperature data, Paleaeogeogr. Palaeoclimatol. Palaeoecol., 98, 129-141.

Zhang, T., T. E. Osterkamp, and K. Stamnes (1996), Influence of the depth hoar layer of the seasonal snow cover on the ground thermal regime, Water Resour. Res., 32(7), 2075-2086.

Zhang, T., T. E. Osterkamp, and K. Stamnes (1997), Effects of climate on the active layer and permafrost on the north slope of Alaska, U.S.A., Permafrost Periglacial Processes, 8, 45-67.

A. Grundstein and T. Mote, Department of Geography, University of Georgia, Athens, GA 30602, USA. (andrewg@uga.edu)

P. Todhunter, Department of Geography, University of North Dakota, Grand Forks, ND 58202-9020, USA. 